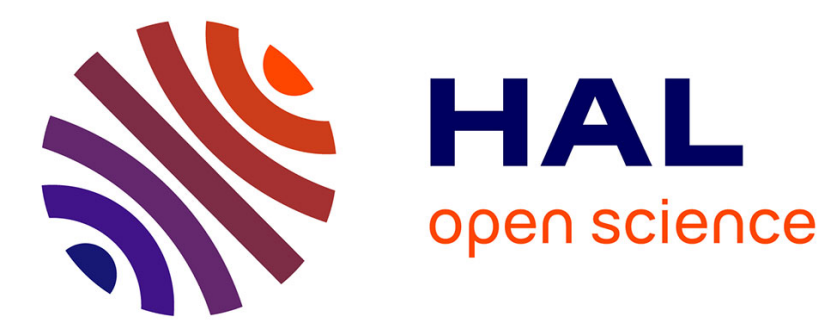

\title{
Burrowing activity of the geophagous earthworm Pontoscolex corethrurus (Oligochaeta: Glossoscolecidae) in the presence of charcoal
}

\author{
Stéphanie Topoliantz, Jean-François Ponge
}

\section{- To cite this version:}

Stéphanie Topoliantz, Jean-François Ponge. Burrowing activity of the geophagous earthworm Pontoscolex corethrurus (Oligochaeta: Glossoscolecidae) in the presence of charcoal. Applied Soil Ecology, 2003, 23 (3), pp.267-271. 10.1016/s0929-1393(03)00063-5 . hal-00498494

\author{
HAL Id: hal-00498494 \\ https://hal.science/hal-00498494
}

Submitted on 7 Jul 2010

HAL is a multi-disciplinary open access archive for the deposit and dissemination of scientific research documents, whether they are published or not. The documents may come from teaching and research institutions in France or abroad, or from public or private research centers.
L'archive ouverte pluridisciplinaire HAL, est destinée au dépôt et à la diffusion de documents scientifiques de niveau recherche, publiés ou non, émanant des établissements d'enseignement et de recherche français ou étrangers, des laboratoires publics ou privés. 
Burrowing activity of the geophagous earthworm Pontoscolex corethrurus

(Oligochaeta: Glossoscolecidae) in the presence of charcoal

Stéphanie TOPOLIANTZ, Jean-François PONGE

Muséum National d'Histoire Naturelle, CNRS-UMR 8571, 4 avenue du Petit-Château, 91800 Brunoy, France

Corresponding author : Stéphanie Topoliantz, tel. +33160479213, fax +331

60465009 ; E-mail Stephanie.Topoliantz@wanadoo.fr

\section{Abstract}

The geophagous earthworm Pontoscolex corethrurus is frequently found in burnt tropical soils where charcoal plays an important role in soil fertility. We studied the burrowing activity of this species in two-dimensional microcosms with one half filled with soil and the other with a $3: 2(\mathrm{w}: \mathrm{w})$ mixture of charcoal and soil (CHAR+soil). We measured the volume of empty burrows and those filled with black or brown casts in both substrates, as well as the initial and final fresh weights of the worms. The correlation between brown cast production and both initial and final fresh weights of the worms, reinforced by the presence of feeding cavities in soil but not in CHAR+soil, suggests that $P$. corethrurus would ingest soil to fulfill its nutrient requirements, in contrast to charcoal which was ingested for other purposes. We observed that at equal burrow volume created in the two substrates, $P$. corethrurus produced smaller black casts than brown casts, suggesting that burrows were created in CHAR+soil mainly by pushing aside the particles of this lighter substrate. 
1 The observed transport of charcoal to soil points to the importance of $P$. corethrurus

2 in the incorporation of charcoal particles into organic-poor soil.

Key-words

Burrows; casts; charcoal; Pontoscolex corethrurus

\section{Introduction}

The geophagous earthworm Pontoscolex corethrurus, an endogeic species feeding on soil with a low content of organic matter (Lavelle et al., 1987), exerts an important effect on the soil structure in the upper $10 \mathrm{~cm}$ through its burrowing and casting activity. While it has been reported to increase the porosity of compacted soil (Zund et al., 1997), P. corethrurus is classified as a "soil compacting" earthworm species (Lavelle et al., 1998) because it produces large coalescent aggregates (Barois et al., 1993). The production of these macroaggregates $(>1 \mathrm{~cm})$ increases bulk density and decreases water infiltration (Alegre et al., 1996), thus causing a strong compaction of the soil surface. This detrimental effect of earthworm activity occurs at a high density of $P$. corethrurus and in the absence of other earthworm species reducing aggregate size (Barros et al., 2001; Chauvel et al., 1999).

Whereas the importance of charcoal in soil fertility has often been reported (Tryon, 1948; Glaser et al., 2001; Lehmann et al., 2002; Topoliantz et al., 2002), no published study has yet dealt with its possible incorporation into the soil by $P$. corethrurus individuals living in burnt areas (Standen, 1988; personal observation) or by other soil fauna. In the present study, we investigated the subterranean activity of $P$. corethrurus and its growth in the presence of soil and charcoal. 


\section{Material and methods}

We studied the burrowing activity of $P$. corethrurus in the presence of native soil and charcoal in two-dimensional microcosms (Evans, 1947; Grant, 1956), made of two parallel transparent plastic sheets each $20 \mathrm{~cm}$ high $\times 25 \mathrm{~cm}$ wide $\times 2 \mathrm{~mm}$ thick. Bottom and side edges were sealed with $2 \mathrm{~mm}$ thick wooden strips, thus allowing earthworm movement and observation of their burrow system and cast deposition. The microcosms were filled with $80 \mathrm{~g}$ dry weight of soil on one side; the other half side was filled with $40 \mathrm{~g}$ dry weight of a 3:2 (w:w) mixture of charcoal and soil (CHAR+soil). The soil was taken from the upper $10 \mathrm{~cm}$ of an oxisol $(65 \%$ sand, $12 \%$ silt and $23 \%$ clay content) in a slash-and-burn field in maripasoula (French Guiana). Charcoal was collected on the ground in a recently burnt field. Both substrates were sieved at $2 \mathrm{~mm}$ mesh size. Physical and chemical properties of the substrates are given in Table 1. Both substrates were moistened from the top edge by adding water to $50-55 \%$ substrate weight. Sub-adult $P$. corethrurus were obtained from a nearby experimental area. In each microcosm, one individual (initial fresh weight from 209 to $591 \mathrm{mg}$ ) was inserted from the top edge at the border between the two substrates. The top edges of the microcosms were closed with Parafilm® to avoid desiccation and earthworm escape. Ten replicates were established and placed for two weeks in a dark chamber with controlled temperature at $25^{\circ} \mathrm{C}$. At the end of the experiment, the surface of burrows and casts visible through the two transparent walls (planes 1 and 2) were drawn on a transparent film and measured with a surface integrator (Numonics $1224 \AA$, resolution $0.1 \mathrm{~mm}$ ). Casts were classified according to their colour, as brown (soil) and black (mixture of charcoal andsoil) casts. Very dark grey 
1 casts were pooled with black ones because of their high content of charcoal. The

2 Mean surface area and the volume of empty and cast-filled burrows were calculated 3 from the following equations:

Mean surface area $=($ area on plane $1+$ area on plane 2$) / 2$

Volume $=$ Mean surface area $\times$ substrate thickness $(2 \mathrm{~mm})$

The burrow length was not measured because a high number of burrows could not be considered as typical linear galleries (see Fig 1 as an example of the burrow system). The final fresh weight of individuals was measured after rinsing earthworms in water and gently blotting them with absorbent paper.

The volume of burrows, the volume of casts filling the burrow system and the growth rate of earthworms were statistically analysed using only nine replicates, one earthworm having died during the experiment. Initial and final fresh weights of worms were compared using paired t-tests. The volumes of casts and burrows in soil, CHAR+soil and both substrates pooled, were compared using t-tests or MannWhitney rank tests when data were not normally distributed. Relationships between growth rate, cast and burrow volume were tested by Bravais-Pearson correlation coefficients. The coefficient of variation (SD/mean $\times 100)$ was calculated for each variable (Sokal and Rohlf, 1995).

\section{Results}


During the experiment, the earthworm weight increased by $36 \pm 17 \%$ (mean \pm

2 S.D.) and the mean growth increment was $0.13 \pm 0.06 \mathrm{~g}$. The final fresh weight $(0.49$

$3 \pm 0.15 \mathrm{~g}$, mean \pm S.D. $)$ was significantly higher than the initial weight $(0.36 \pm 0.11 \mathrm{~g}$, mean \pm S.D. $)$ at the 0.001 level $(t=-6.12)$. No significant correlation was found between the growth rate and other variables such as initial fresh weight or burrow and cast volume, whether substrates were pooled or not. The initial fresh weight of worms was positively correlated with the volume of total burrows calculated when both substrates were pooled $(r=0.736, P<0.05)$ and with the total volume of brown casts deposited $(r=0.82, P<0.01)$. The final fresh weight of worms was positively correlated with the total brown cast volume $(r=0.83, P<0.01)$ and with the total brown cast / soil burrow volume ratio $(r=0.695, P<0.05)$. Initial and final fresh weights were not correlated with either black cast deposition or with burrowing activity in CHAR+soil.

On average, in the total substrate, $P$. corethrurus created burrows of $3.34 \pm$ $0.74 \mathrm{~cm}^{3}$ (mean \pm S.D.) per $\mathrm{g}$ of earthworm biomass and per day. After 14 days, the burrow system in the soil substrate reached $32.4 \pm 8.8 \%$ (mean \pm S.D.) of the total soil volume and the burrow system in CHAR+soil $3.9 \pm 2.4 \%$ (mean \pm S.D.) of the total CHAR+soil volume. Total brown casts deposited on both sides (soil and CHAR+soil) and burrows in the soil half side were strongly correlated $(r=0.92$, $\mathrm{P}<0.001)$, as were total black casts and burrows in CHAR+soil $(r=0.95, P<0.001)$. The total volume of brown casts amounted to $37.3 \%$ of the burrow system on the soil half side and the total volume of black casts $10.6 \%$ of the burrow system in CHAR+soil (Table 2).

Comparisons of burrow systems and cast deposition between soil and CHAR+soil are summarised in Table 2. The initial volumes of soil and CHAR+soil 
1 were not significantly different. The volume of the burrow system in the soil half side 2 was significantly higher than that in the $\mathrm{CHAR}+$ soil half side and the total volume of brown casts deposited on both sides was significantly higher than that of black casts. The ratio of total brown casts to burrows in soil was higher than that of black casts to burrows in CHAR+soil. The percentage of burrows filled with casts (black and brown) in soil was not significantly different to that in CHAR+soil. Coefficients of variation were greater for black casts and CHAR+soil burrows than for brown casts and soil burrows, indicating that burrowing and cast production were more variable in CHAR+soil than in soil (Table 2). The ratio of black casts deposited in soil to total black casts was not different of that of brown casts deposited in CHAR+soil to total brown casts, both displaying a high coefficient of variation (Table 2).

\section{Discussion}

Heavier individuals of $P$. corethrurus constructed more channels, as Lavelle et al. (1998) found for immature individuals only (weighing less than $0.6 \mathrm{~g}$ fresh weight). Bigger immature earthworms ingested more soil but not more charcoal-soil mixture than smaller ones, suggesting that, although no correlation between soil ingestion and earthworm growth was found, the soil constituted a nutrient source in contrast to charcoal. This result is reinforced by the presence of feeding cavities in soil only (Fig.1), which are burrowed to exploit a food source (Martin, 1982). The mean growth rate of $P$. corethrurus appears lower (2.5\% per day) than that found by Lavelle et al. (1987) (5 to $6 \%$ per day) at the same soil moisture, despite a similar soil consumption (5.4 g soil per $\mathrm{g}$ earthworm fresh weight). We can attribute this difference to the estimating method of soil consumption, Lavelle et al. (1987) results being based on 
1 the weight of casts produced and ours on burrow volume and soil bulk density. In our

2 2D microcosms, the soil was poorly compacted and allowed channelling activity without necessariy ingestion of the substrate (Buck et al., 2000).

If all the burrow volume had been ingested by the worms, the ratio of black cast/burrow volume in the charcoal/soil mixture $(11 \%)$ and that of brown cast/burrow volume in soil (37\%) would represent a compaction of the ingested substrate of 9.4 and 2.7 for charcoal/soil and soil respectively. This result cannot totally be explained by differences in bulk density (Table 1 ) and suggests that $P$. corethrurus may have created channels in the charcoal/soil substrate mainly by pushing aside charcoal particles and to a lesser extent by ingesting them. The microcosms being highly artificial, the worms could ingest charcoal by accident as Fig 1 shows. However, $P$. corethrurus, that selects particles before ingestion (Lavelle, 1997), could ingest charcoal for its detoxifying and liming effects (Titoff, 1910;; Zackrisson et al., 1996) and its enhancment of microbial communities (Pietikainen et al., 2000) which could favour the production of earthworm's digestive enzymes of bacterial origin (Lattaud et al., 1999).

The transport of ingested matter, here demonstrated through black and brown cast deposition, underlines the importance of $P$. corethrurus for bioturbation (Garcia and Fragoso, 2002). More especially, by ingesting charcoal and incorporating it to the soil matrix, $P$. corethrurus could play an important role in burying this source of fertility in burnt soils used for slash-and-burn agriculture (Topoliantz et al., 2002).

\section{Acknowledgements}

We thank the SOFT Program of the French Ministry for the Environment, the PPFGuyane of the Museum National d'Histoire Naturelle and the GIS-SILVOLAB of 
1 French Guiana for their financial support. We are grateful to our colleagues $\mathrm{Dr}$

2 Nicolas Bernier and Prof. Pierre Arpin for their technical help in drawing Figure 1.

\section{References}

Alegre, J.C., Pashanasi, B., Lavelle, P., 1996. Dynamics of soil physical properties in Amazonian agroecosystems inoculated with earthworms. Soil Sc. Soc. Am. J. $60,1522-1529$.

Barois, I., Villemin, G., Lavelle, P., Toutain, F., 1993. Transformation of the soil structure through Pontoscolex corethrurus (Oligochaeta) intestinal tract. Geoderma 56, 57-66.

Barros, E., Curmi, P., Hallaire, V., Chauvel, A., Lavelle, P., 2001. The role of macrofauna in the transformation and reversibility of soil structure of an oxisol in the process of forest to pasture conversion. Geoderma 100, 193-213.

Buck, C., Langmaack, M., Schrader, S., 2000. Influence of mulch and soil compaction on earthworm cast properties. Appl. Soil Ecol. 14, 223-229.

Chauvel, A., Grimaldi, M., Barros, E., Blanchart, E., Desjardins, T., Sarrazin, M., Lavelle, P., 1999. Pasture damage by an Amazonian earthworm. Nature 398, 32-33.

Evans, A.C., 1947. A method of studying the burrowing activities of earthworms. Ann. Mag. Nat. Hist. 14, 643-650.

Garcia, J.A., Fragoso, C., 2002. Growth, reproduction and activity of earthworms in degraded and amended tropical open mined soils: laboratory assays. Appl. Soil Ecol. 20, 43-56. 
1 Glaser, B., Haumaier, L., Guggenberger, G., Zech, W., 2001. The 'Terra Preta' phenomenon: a model for sustainable agriculture in the humid tropics. Naturwissenschaften 88, 37-41.

Grant, W.C. Jr, 1956. An ecological study of the peregrine earthworm Pheretima hypeiensis in the eastern United States. Ecology 37, 648-658.

Lattaud, C., Mora, P., Garvin, M., Locati, S., Rouland, C., 1999. Enzymatic digestive capabilities in geophagous earthworms - origin and activities of cellulolytic enzymes. Pedobiologia 43, 842-850.

Lavelle, P., Barois, I., Cruz, I., Fragoso, C., Hernandez, A., Pineda, A., Rangel, P., 1987. Adaptive strategies of Pontoscolex corethrurus (Glossoscolecidae, Oligochaeta), a peregrine geophagous earthworm of the humid tropics. Biol. Fert. Soils 5, 188-194.

Lavelle, P., 1997. Faunal activities and soil processes: adaptive strategies that determine ecosystem function. Adv. Ecol. Res. 27, 93-132.

Lavelle, P., Pashanasi, B., Charpentier, F., Gilot, C., Rossi, J.P., Derouard, L., Andre, J., Ponge, J.F., Bernier, N., 1998. Large-scale effects of earthworms on soil organic matter and nutrient dynamics. In: EDWARDS, C.A. (Eds.), Earthworm ecology. Saint Lucie Press, Boca Raton, Florida, pp. 103-122.

Lehmann, J., Da Silva, J.P.Jr, Rondon, M., Da Silva, C.M., Greenwood, J., Nehls, T., Steiner, C., Glaser, B., 2002. Slash-and-char: a feasible alternative for soil fertility management in the Central Amazon? In: Soil Science: Confronting New realities in the 21 st Century. $17^{\text {th }}$ World Congress of Soil Science, Bangkok, Symposium 13, 449:1-12. 
1 Martin, N.A., 1982. The interaction between organic matter in soil and the burrowing activity of three species of earthworms (Oligochaeta: Lumbricidae). Pedobiologia 24, 185-190.

Pietikäinen, J., Kiikkilä, O., Fritze, H., 2000. Charcoal as habitat for microbes and its effect on the microbial community of the underlying humus. OIKOS 89, 231242.

Sokal, R.R., Rohlf, F.J., 1995. Biometry. Freeman W H and Company, New York, $887 \mathrm{pp}$.

Standen, V., 1988. Oligochaetes in fire climax grassland and conifer plantations in Papua New Guinea. J. Trop. Ecol. 4, 39-48.

Titoff, A., 1910. Die Adsorption von Gasen durch Kohle. Zeitschrift für Physikalische Chemiestochiometrie und Verwandtschaftslehre 74, 641-678.

Topoliantz, S., Ponge, J.F., Arrouays, D., Ballof, S., Lavelle, P., 2002. Effect of organic manure and the endogeic earthworm Pontoscolex corethrurus (Oligochaeta: Glossocscolecidae) on soil fertility and bean production. Biol. Fertil. Soils 36, 313-319.

Tryon, E.H., 1948. Effect of charcoal on certain physical, chemical, and biological properties of forest soils. Ecol. Monogr. 18, 81-115.

Zackrisson, O., Nilsson, M.C., Wardle, D.A., 1996. Key ecological function of charcoal from wildfire in the Boreal forest. Oikos 77, 10-19.

Zund, P.R., Pillai-Mc Garry, U., Mc Garry, D., Bray, S.G., 1997. Repair of a compacted Oxisol by the earthworm Pontoscolex corethrurus (Glossoscolecidae, Oligochaeta). Biol. Fert. Soils 25, 202-208. 
Fig. 1. Example of a reconstructed burrow system in soil and charcoal / soil 2 mixture made in two weeks by one individual Pontoscolex corethrurus $(0.35 \mathrm{~g}$ initial 3 fresh weight) at $25^{\circ} \mathrm{C}$. The image of the burrow system was obtained by 4 superimposing drawings done on the two walls of one microcosm. Black and brown 5 casts are represented by black and horizontal strips, respectively. Voids represent 6 ingested or pushed aside areas.

7 
Table 1

Chemical and physical properties ( $\mathrm{pH}$, total $\mathrm{C}$ and $\mathrm{N}$ content) of substrates used in the microcosms

\begin{tabular}{|c|c|c|c|c|c|}
\hline Substrate & $\mathrm{pH}$ & C (\%) & $\mathrm{N}(\%)$ & C:N ratio & Mass:volume ratio $\left(\mathrm{g} \mathrm{cm}^{-3}\right)$ \\
\hline Soil & 4.63 & 2.88 & 0.215 & 13.40 & 1.77 \\
\hline Mixture charcoal+soil & 6.90 & 39.46 & 0.299 & 132.07 & 0.885 \\
\hline
\end{tabular}

2 
Table 2

Comparison of burrowing actvity and cast deposition of Pontoscolex corethrurus after 2 weeks between soil and charcoal+soil (CHAR+soil), $(n=9)$. Volumes and ratios (mean \pm S.D.) were compaired by $t$-test ( $t$ ) or MannWhitney rank test $(T)$. Significant probability is indicated by * ${ }^{* *}$, ${ }^{* * *}$ for $P<0.05, P<0.01$ and $P<0.001$ respectively and no significant differences are abbreviated NS. CV (\%) is the coefficient of variation.

\begin{tabular}{|c|c|c|c|c|}
\hline Variables & Unity & Mean \pm S.D. & CV $(\%)$ & $\mathrm{t}$ or $\mathrm{T}$ \\
\hline Initial soil volume & $\mathrm{cm}^{3}$ & $45.12 \pm 1.34$ & 2.97 & \multirow{2}{*}{$\mathrm{t}=-0.118 \mathrm{NS}$} \\
\hline Initial CHAR+soil volume & $\mathrm{cm}^{3}$ & $45.19 \pm 1.16$ & 2.57 & \\
\hline Burrow volume in soil & $\mathrm{cm}^{3}$ & $14.60 \pm 3.95$ & 27.03 & \multirow{2}{*}{$\mathrm{T}=126 * * *$} \\
\hline Burrow volume in $\mathrm{CHAR}+$ soil & $\mathrm{cm}^{3}$ & $1.76 \pm 1.16$ & 65.95 & \\
\hline Volume of total brown casts & $\mathrm{cm}^{3}$ & $5.46 \pm 1.68$ & 30.81 & \multirow{2}{*}{$\mathrm{T}=126^{* * *}$} \\
\hline Volume of total black casts & $\mathrm{cm}^{3}$ & $0.25 \pm 0.32$ & 130.11 & \\
\hline Total brown casts/burrows in soil & $\%$ & $37.3 \pm 4.9$ & 13.27 & \multirow{2}{*}{$\mathrm{t}=8.460^{\star \star \star}$} \\
\hline Total black casts/burrows in CHAR+soil & $\%$ & $10.6 \pm 8.1$ & 75.94 & \\
\hline Total casts in soil/burrows in soil & $\%$ & $34.7 \pm 4.8$ & 13.9 & \multirow{2}{*}{$t=1.629 \mathrm{NS}$} \\
\hline Total casts in CHAR+soil/ burrows in CHAR+soil & $\%$ & $27.6 \pm 12.2$ & 44.06 & \\
\hline Brown casts in $\mathrm{CHAR+soil/total} \mathrm{brown} \mathrm{casts}$ & $\%$ & $7.36 \pm 8.04$ & 109.34 & \multirow{2}{*}{$\mathrm{T}=76 \mathrm{NS}$} \\
\hline Black casts in soil/total black casts ${ }^{1}$ & $\%$ & $33.2 \pm 29.8$ & 89.97 & \\
\hline
\end{tabular}

${ }^{1}$ Only seven replicates used, due to the absence of black casts in the other two. 


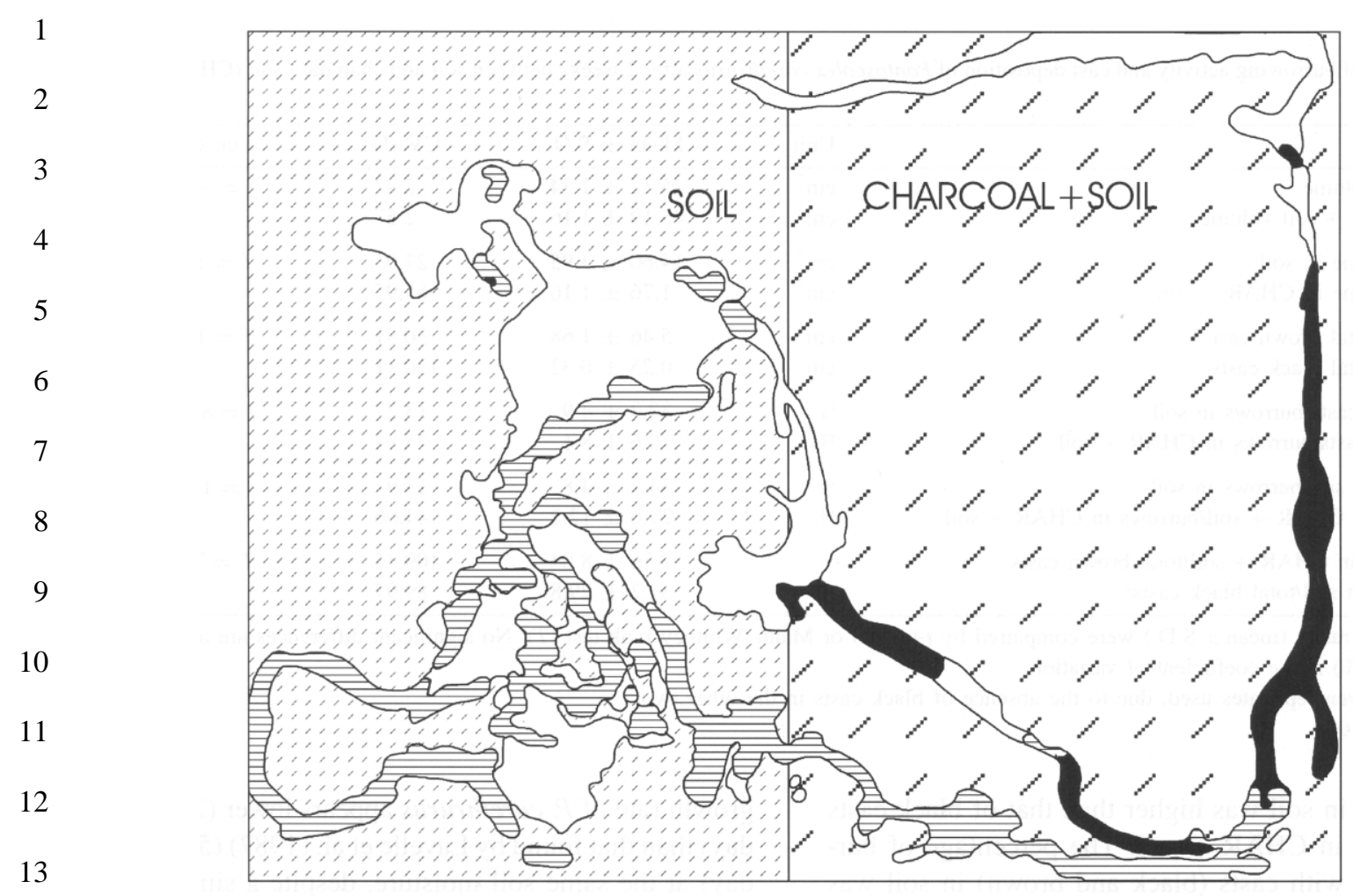

$14 \quad$ Fig. 1 